\title{
Perbadingan Pembersihan Bulu Halus Antara Penggunaan Lilin Siongka dan Pemanggangan Terhadap Kualitas Karkas Itik
}

\author{
Moh. Amir Biqi, Bachtar Bakrie, Maria Aditya Wahyuningrum \\ Program Studi Agroteknologi Fakultas Pertanian Universitas Respati Indonesia \\ Email : moh.amirbiqi@gmail.com
}

\begin{abstract}
Abstrak
Proses mendapatkan karkas itik terdapat kesulitan pada pembersihan bulu halusnya. Pelaku usaha pemotongan itik menambah prosesnya dengan lilin siongka atau pemanggangan. Penelitian ini dilakukan untuk mengetahui perbandingan kualitas fisik dan mikrobiologis karkas itik dengan perlakukan pembersihan bulu halus berbeda. Penelitian menggunakan Rancangan Acak Lengkap Faktorial (2x2). Perlakukanya yaitu dengan cara pembersihan dan jenis itik yang digunakan dengan delapan ulangan meliputi: Lilin siongka+itik lokal (P1L1), Lilin siongka+itik hibrida (P1L2), Pemanggangan+itik lokal (P2L1) dan Pemanggangan+itik hibrida (P2L2). Parameter yang diamati adalah persentase karkas, persentase mutu karkas, tingkat kesukaan karkas dan cemaran mikrobiologi. Hasil analisis statistik persentase karkas lebih tinggi $(P<0,05)$ pada pembersihan dengan lilin siongka $(61,27 \%)$ dibandingkan pembersihan dengan pemanggangan P2L1 (57,09\%). Persentase mutu faktor keutuhan paling tinggi pada P1L1 (75 \%) sedangkan faktor kebersihan paling tinggi P2L2 (88\%). Tingkat kesukaan warna karkas tidak berbeda nyata $(P>0,05)$, aroma karkas pemanggangan lebih disukai $(P<0,05)$. Cemaran Eschericia coli tertinggi $110 \times 10^{1} \mathrm{MPN} / \mathrm{g}$ (P2L1) dimana pada penilaian mutu kebersihan mendapatkan nilai terendah. Semua perlakukan menunjukkan hasil negatif salmonella.
\end{abstract}

Kata kunci : Itik, karkas, lilin siongka, pemanggangan

\begin{abstract}
The process of getting a duck carcass has difficulties in cleaning the pin feather. Slaughterhouse actors in RPHU Rorotan add to the process with siongka wax or roasting treatment. The purpose of this study is to know the physical and microbiological quality of duck carcasses with different cleaning treatments and determine the effect of type of duck that is local duck and hybrid duck. To achieve that goal, then conducted a study using a randomized block factorial $(2 \times 2)$. Treatments were cleaning pin feather method and type of duck with 8 replications, consist of: siongka wax +local duck (P1L1), siongka wax + hybrid duck (P1L2), roasting + local duck (P2L1) and roasting + hybrid duck (P2L2). The parameters are observed in this study are the percentage of carcass, the percentage of quality carcass, sensory quality of duck carcass and microbiological contamination. The study showed that significant differences $(P<0,05)$ of the percentage of carcass with siongka wax $(61,27 \%)$. The highest was percentage of wholeness quality carcass on P1L1 (75\%) while in cleanliness quality on P2L2 (88\%). Sensory quality of duck carcass on carcass color found no differences with other treatments $(P>0,05)$. Majorly, carcass flavor with roasting showed significant differences $(P<0,05)$. Escherichia coli contamination at the highest value $110 \times 10^{1} \mathrm{MPN} / \mathrm{g}$ (P2L1) where is on cleanliness quality showed at the lowest value. All treatments no Salmonella found.
\end{abstract}

Keyword : duck, carcass, siongka wax, roasting 


\section{PENDAHULUAN}

Olahan daging itik saat ini semakin banyak digemari oleh masyarakat khususnya di Jakarta. Banyak bermunculan rumah makan maupun warung tenda yang secara khusus menyediakan olahan daging itik. Hal tersebut didukung oleh data peningkatan produksi daging itik di Provinsi DKI Jakarta selama tahun 2018 dan 2019. Peningkatan produksi daging itik mengalami kenaikan 3 kali lipat selama tahun 2019 yaitu tercatat sebesar $1.093 .929 \mathrm{~kg}$ dibandingkan pada tahun 2018 hanya tercatat sebesar 366.211 $\mathrm{kg}[9]$.

Daging itik mengandung zat gizi tinggi yang baik untuk kesehatan dan pertumbuhan manusia serta sangat baik juga sebagai media perkembangan mikroorganisme. Mikroorganisme yang berkembang pada daging dapat terjadi karena daging segar mengalami kontaminasi. Kontaminasi pada daging dapat terjadi selama proses penyiapan dan penanganan karkas [7]. Cemaran mikroorganisme pada daging terjadi oleh beberapa mikroorganisme seperti Mesophiles, Psychrotrophs, Koliform, Escherichia coli dan Salmonella. Bakteri Eschericia coli sering didapatkan dari kulit dan bulu unggas [12].

Salah satu tahap yang sangat menentukan kualitas dan keamanan daging yaitu pada tahap di Rumah Pemotongan Hewan (RPH). Di sini terjadi perubahan dari otot (hewan hidup) ke daging, serta dapat terjadi pencemaran mikroorganisme. Berdasarkan pemantauan di lapangan penyiapan karkas itik dilakukan dalam beberapa proses, salah satunya pembersihan bulu. Tindakan pembersihan bulu meliputi penghilangan bulu utama, bulu halus dan bulu rambut. Terdapat perbedaan dalam proses scalding dan pencabutan pada itik dan angsa [17].

Pembersihan bulu halus dan bulu rambut itik oleh pemotong ditambah prosesnya dengan melakukan pencelupan dalam lilin panas maupun dengan pemanggangan. Kesulitan dalam proses pembersihan bulu tersebut diduga dapat menyebabkan penurunan kualitas karkas itik baik secara fisik maupun secara mikrobiologis. Scalding dalam lilin panas pada pencabutan bulu itik tidak berpengaruh terhadap nilai susut masak dan sobek kulit namun berpengaruh terhadap kadar lemak dan kecerahan [16]. Namun berdasarkan pemantauan di lapangan dapat menyebabkan pencemaran lingkungan berupa sisa lilin yang mengeras disekitar tempat pemotongan dan menjadikan susah untuk dibersihkan.

Sedangkan proses pembersihan bulu dengan pemanggangan dipercaya dapat meningkatkan aroma khasnya karena flavor daging unggas secara alami terbentuk melalui proses tertentu, misalnya pemanasan [18]. Komponen flavor utama 
daging berupa komponen volatil dan nonvolatil mempunyai pengaruh besar terhadap penerimaan daging, terutama terhadap rasa (taste). Namun, berdasarkan pemantauan di lapangan proses pembersihan dengan pemanggangan dapat menyebabkan warna karkas itik menjadi lebih coklat akibat proses pembakaran.

Pemilihan proses pembersihan bulu itik tersebut seringnya dipengaruhi oleh permintaan konsumen dan kebiasaan pelaku pemotongan itik tanpa mempertimbangkan pengaruh perlakuan terhadap kualitas karkas itik. Hal tersebut tentu menjadi tantangan bagi pemangku kebijakan untuk memberikan jaminan keamanan daging itik yang dihasilkan. Perbandingan pengaruh kualitas fisik dan mikrobiologis terhadap perlakuan pembersihan bulu halus dengan lilin siongka dan pemanggangan di Rumah Potong Hewan Unggas Rorotan belum pernah diteliti untuk mendapatkan informasi ilmiah yang cukup agar diketahui nilai perbandingan kualitas karkas yang mendapatkan perlakukan pembersihan bulu halus yang berbeda.

Pemerintah Provinsi DKI Jakarta dari tahun 2018 telah meresmikan rumah potong hewan khusus itik yaitu RPHU Rorotan yang berlokasi di Kelurahan Rorotan Kecamatan Cilincing Kota Jakarta Utara. Sedikitnya terdapat tiga jenis itik yang sering menjadi komoditas pemotongan di RPHU Rorotan yaitu itik lokal, itik hibrida dan itik peking. Berdasarkan pemantauan dilapangan itik peking mempunyai proporsi paling yaitu sebesar $50 \%$, dilanjutkan oleh itik lokal $30 \%$ dan itik hibrida 20\%. Itik peking mempunyai bobot hidup yang 3 kali lipat dibandingkan dengan itik lokal dan itik hibrida sehingga untuk membandingkan perlakuan pembersihan bulu halus digunakan itik lokal dan itik hibrida.

\section{METODE PENELITIAN}

\section{Materi/Ternak Percobaan}

Penelitian ini menggunakan 32 ekor yang terdiri dari 16 ekor itik lokal dan 16 ekor itik hibrida dengan bobot hidup rata rata itik lokal 849 gram dan itik hibrida 1178 gram. Itik diperoleh dari kandang penampungan sementara di RPHU Rorotan. Beberapa peralatan digunakan untuk percobaan penggunaan lilin siongka: pisau, panci, lilin siongka, dan wadah penampung; pemanggangan : kompor gas, alas pembakaran; pengukuran bobot karkas : plastik seal dan timbangan digital.

\section{Rancangan Penelitian}

Rancangan peneitian yang
digunakan dalam penelitian ini adalah
dengan Rancang Acak Lengkap (RAL)
Faktorial dengan dua faktor yang terdiri atas
masing-masing 2 perlakuan dan 8 ulangan
sehingga total keseluruhan unit percobaan
adalah 32 ekor itik. Faktor pertama adalah
cara pembersihan bulu halus itik yaitu P1 =


pembersihan bulu halus itik dengan lilin siongka, $\mathrm{P} 2=$ pembersihan bulu halus itik dengan pemanggangan. Faktor kedua adalah jenis itik yaitu , L1 = itik lokal dan L2 = itik hibrida

\section{Pelaksanaan Penelitian}

Pelaksanaan penelitian mencakup proses membersihkan bulu halus yang dibagi menjadi 2 kelompok perlakuan yaitu menggunakan lilin siongka cair dan menggunakan pemanggangan dengan kompor gas. Proses pengambilan data penelitian ini dilaksanakan sebanyak dua kali yaitu tanggal 01 April 2021 dan 06 April 2021 dengan total itik yang digunakan sebanyak 32 ekor terdiri dari 16 ekor itik lokal dan 16 ekor itik hibrida.

Pada tahap pertama diberikan perlakukan pembersihan bulu halus dengan lilin siongka dan pemanggangan terhadap jenis itik lokal dan itik hibrida masing masing sebanyak empat kali ulangan. Sehingga jumlah itik yang digunakan sebanyak 16 ekor. Begitu juga dengan tahap kedua perlakuan yang diberikan sama dengan tahap pertama sehingga jumlah itik yang digunakan juga sama yaitu sebanyak 16 ekor.

Setelah itik selesai diberikan perlakuan pembersihan bulu halus baik dengan lilin siongka maupun pemanggangan kemudian dipisahkan bagian kepala, kaki dan jeroannya serta dilakukan penimbangan terakhir sebagai data bobot karkas. Data bobot karkas diambil pada tahap pertama dan kedua penelitian. Kemudian masingmasing perlakuan dilakukan pengambilan sampel untuk dilakukan pengujian laboratorium. Karkas itik lalu dibawa ke Laboratorium Kesehatan Masyarakat Veteriner dalam kondisi terbungkus plastik dengan seal dan dimasukan ke dalam cool box yang telah diberi es.

\section{Parameter penelitian}

Dalam penelitian ini parameter yang diuji adalah kualitas fisik dan mikrobiologi karkas yang dihasilkan dari dua perlakuan yang diberikan. Kualitas fisik dilakukan penilaian mutu karkas dan uji hedonik sedangkan uji mikrobiologi dengan uji kandungan Eschericia coli dan Salmonella.

\section{Penilaian Mutu Karkas}

Mutu karkas ditentukan berdasarkan Standar Nasional Indonesia nomor 3924 tahun 2009 sebagaimana tabel 1. Terkait dengan tema penelitian setiap karkas hanya dinilai tingkatan mutu karkasnya berdasarkan faktor mutu keutuhan kulitnya dan kebersihannya. Penilaian menggunakan metode penilaian karakteristik makroskopis. 
Tabel 1. Persyaratan tingkatan mutu fisik karkas keutuhan dan kebersihan

\begin{tabular}{|c|c|c|c|c|}
\hline \multirow{2}{*}{ No. } & \multirow{2}{*}{ Faktor Mutu } & \multicolumn{3}{|c|}{ Tingkatan Mutu } \\
\hline & & Mutu I & Mutu II & Mutu III \\
\hline 1. & Keutuhan & Utuh & $\begin{array}{l}\text { Kuit sobek sedikit, } \\
\text { tetapi tidak pada } \\
\text { bagian dada }\end{array}$ & $\begin{array}{l}\text { Ada kulit yang sobek } \\
\text { pada bagian dada }\end{array}$ \\
\hline 2. & Kebersihan & $\begin{array}{l}\text { Bebas dari } \\
\text { bulu tunas } \\
\text { (pin feather) }\end{array}$ & $\begin{array}{l}\text { Ada bulu tunas } \\
\text { sedikit yang } \\
\text { menyebar, tetapi } \\
\text { tidak pada bagian } \\
\text { dada }\end{array}$ & Ada bulu tunas \\
\hline
\end{tabular}

Sumber : Badan Standarisasi Nasional (2009)

\section{Uji Hedonik}

Nilai kesukaan karkas ditentukan dengan cara penilaian organoleptik penampilan karkas itik oleh 25 orang panelis tidak terlatih [23]. Sampel karkas dinilai tingkat kesukaannya berdasarkan warna, aroma dan tekstur karkas itik. Setiap panelis mendapatkan formulir uji kesukaan dan mengisi formulir tersebut sesuai dengan penilaian kesukaan terhadap aspek yang dinilai. Panelis memberikan penilaian berdasarkan kriteria yang sudah ditentukan dengan skala hedonik sebagaimana tabel 2.

Tabel 2. Skala Hedonik

\begin{tabular}{lllc}
\hline \multicolumn{1}{c}{ Warna } & \multicolumn{1}{c}{ Aroma } & \multicolumn{1}{c}{ Tekstur } & Skor \\
\hline Sangat suka & Sangat suka & Sangat suka & 5 \\
Suka & Suka & Suka & 4 \\
Biasa & Biasa & Biasa & 3 \\
Kurang Suka & Kurang Suka & Kurang Suka & 2 \\
Tidak Suka & Tidak Suka & Tidak Suka & 1 \\
\hline
\end{tabular}

Sumber : (Setyaningsih et al., 2010)

\section{Pemeriksaan Sampel untuk Uji Bakteri}

\section{Eschericia Coli dan Salmonella}

Pemeriksaan sampel untuk pengujian cemaran mikroba Eschericia coli dan Salmonella akan dilakukan oleh Laboratorium Kesehatan Masyarakat Veteriner Pusat Pelayanan Kesehatan
Hewan dan Peternakan DKI Jakarta sesuai dengan SNI 2897: 2008 tentang metode pengujian cemaran mikroba dalam daging, telur dan susu serta hasil olahannya. Karkas itik yang akan diuji dilakukan pembungkusan dengan plastik seal dan segera dikirim ke laboratorium dengan box berpendingin setelah proses perlakuakn selesai 
dilaksanakan. Pada prinsipnya pengujian dilakukan dengan uji pendugaan, uji peneguhan, dan isolasi-identifikasi melalui uji biokimia indole, Methyl red, VogesProskaeur dan Citrate (IMViC) [3]. Pada prinsipnya pengujian dilakukan dengan menumbuhkan salmonella pada media selektif dengan pra pengayaan (Preenrichment), dan pengayaan (enrichment) yang dilanjutkan dengan uji biokimia dan uji serologi [3].

\section{Analisis Data}

Analisis data dari semua parameter yang diukur dilakukan menggunakan analisis sidik ragam (ANOVA) dalam Rancangan Acak Lengkap Faktorial untuk mengetahui adanya perbedaan antar perlakuan dengan menggunakan program komputer Statistical Product and Service Solutions (SPSS) versi 16.0. Apabila hasil analisis statistik menunjukkan perbedaan yang nyata antar perlakuan, maka dilanjutkan dengan Uji Duncan Multiple Range Test (DMRT) .

\section{HASIL DAN PEMBAHASAN}

Proses pengambilan data penelitian ini dilaksanakan sebanyak dua kali yaitu tanggal 01 April 2021 dan 06 April 2021 dengan total itik yang digunakan sebanyak 32 ekor terdiri dari 16 ekor itik lokal dan 16 ekor itik hibrida dengan bobot hidup rata rata itik lokal 849 gram dan itik hibrida 1178 gram. Itik dilakukan pemotongan sampai dengan pencabutan bulu dengan alat dan proses yang sama. Setelah itu diberikan perlakukan pembersihan bulu halus dengan lilin siongka dan pemanggangan.

$$
\text { Pada tahap pertama diberikan }
$$
perlakukan pembersihan bulu halus dengan lilin siongka dan pemanggangan terhadap jenis itik lokal dan itik hibrida masing masing sebanyak empat kali ulangan. Sehingga jumlah itik yang digunakan sebanyak 16 ekor. Begitu juga dengan tahap kedua perlakuan yang diberikan sama dengan tahap pertama sehingga jumlah itik yang digunakan juga sama yaitu sebanyak 16 ekor.

Setelah itik selesai diberikan perlakuan pembersihan bulu halus baik dengan lilin siongka maupun pemanggangan kemudian dipisahkan bagian kepala, kaki dan jeroannya serta dilakukan penimbangan terakhir sebagai data bobot karkas. Data bobot karkas diambil pada tahap pertama dan kedua penelitian. Kemudian masingmasing perlakuan dilakukan pengambilan sampel untuk dilakukan pengujian mikrobiologi di Laboratorium Kesehatan Masyarakat Veteriner DKI Jakarta.

\section{Kualitas Fisik Karkas Itik}

Menurut Soekarto (2020) karkas merupakan hasil awal utama dari proses pemotongan ternak yaitu bagian dari tubuh ternak setelah dikurangi darah, kepala, kaki 
serta isi jeroannya [25]. Hasil penelitian terhadap bobot hidup, bobot karkas dan persentase karkas ternak itik yang digunakan dalam penelitian disajikan pada tabel 3. Rasio bobot karkas terhadap bobot hidup potong dinyatakan dalam persen disebut persentase karkas. Persentase karkas itik berkisar antara 60-68\% [27].

Tabel 3. Berat hidup, berat karkas dan persentase karkas itik

\begin{tabular}{lcccc}
\hline \multicolumn{1}{c}{ Parameter } & P1L1 & P1L2 & P2L1 & P2L2 \\
\hline Berat hidup (g) & 849,00 & 1168,13 & 848,75 & 1187,50 \\
Berat karkas (g) & 483,75 & 773,63 & 448,25 & 727,50 \\
Persentase karkas (\%) & $56,95^{\text {ab }}$ & $65,60^{\mathrm{c}}$ & $52,97^{\mathrm{a}}$ & $61,22^{\mathrm{bc}}$ \\
\hline
\end{tabular}

Hasil analisis statistik terhadap persentase karkas itik menunjukkan itik hibrida (Perlakuan P1L2 dan P2L2) mempunyai persentase karkas lebih tinggi $(P<0,05)$ dibandingkan dengan itik lokal. Adapun persentase karkas itik dengan cara pembersihan bulu halus dengan lilin siongka lebih baik dibandingkan dengan pemanggangan meskipun dengan jenis itik yang berbeda.

Hal tersebut dikarenakan pada proses pembersihan bulu halus dengan pemanggangan terjadi penguapan atau pengeluaran air dan lemak karkas menjadi minyak akibat proses pemanasan secara langsung dengan api sehingga memengaruhi bobot karkasnya. Rata-rata berat minyak yang keluar berkisar 3-11 gram tergantung jenis itik dan bobot hidupnya. Kualitas fisik, kimia dan biokimia daging dipengaruhi oleh faktor genetik dan lingkungan serta kemungkinan interaksi antara genetik dan lingkungan, atau faktor antemortem dan postmortem [27].

Penilaian kualitas fisik karkas itik dilakukan dengan pemeriksaan mutu karkas dengan menggunakan metode penilaian karakteristik makroskopis karkas berdasarkan standar nasional. Hasil penilaian disajikan berupa persentase dari parameter keutuhan dan kebersihan karkas agar dapat mengetahui kualitas karkas yang paling banyak dalam memenuhi kriteria Mutu I, Mutu II dan Mutu III sesuai dengan standar nasional. Hasil penilaian mutu karkas faktor mutu keutuhan karkas yang diberikan perlakuan percobaan adalah sebagai berikut : 


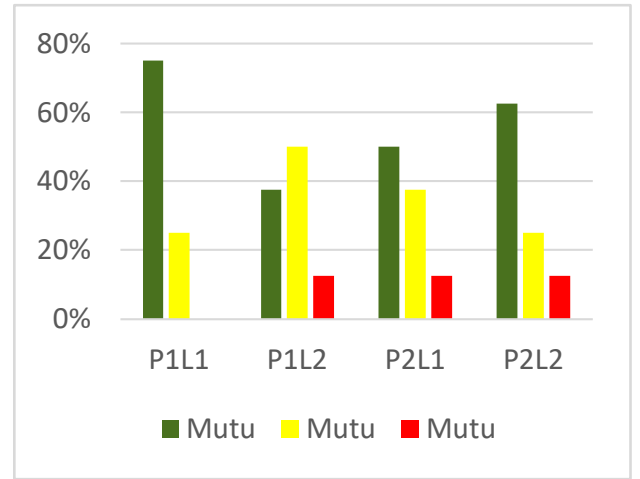

Gambar 1. Diagram penilaian mutu keutuhan karkas

Berdasarkan grafik diatas didapatkan bahwa faktor mutu keutuhan karkas yang menunjukkan presentase karkas mutu I paling banyak yaitu perlakukan P1L1 dengan presentase $75 \%$, disusul perlakuan P2L2 dengan presentase 63\% kemudian perlakukan P2L1 dengan presentase 50\% dan paling rendah perlakuan P1L2 dengan presentase 38\%. Perlakuan P1L2 memiliki presentase mutu I paling rendah karena Sebagian besar karkas yang mengalami sobek kulit pada bagian dada. Hal tersebut terjadi dimungkinkan karena kulit itik hibrida yang cenderung lebih lunak daripada kulit itik lokal. Sedangkan pada perlakuan P2L1 banyak mengalami robek kulit pada bagian dada pada proses pemanggangan karena mengandung sedikit lemak dibawah kulitnya. Kandungan lemak dalam daging antara lain dipengaruhi oleh bangsa, lokasi otot, macam otot, jenis kelamin, dan umur ternak [1].
Adapun hasil penilaian mutu karkas faktor mutu kebersihan setelah diberikan perlakuan adalah sebagai mana gambar 2 . Berdasarkan grafik tersebut didapatkan bahwa faktor mutu kebersihan karkas yang menunjukkan persentase mutu I paling banyak yaitu perlakukan P2L2 sebesar $88 \%$, disusul P1L2 sebesar 50\%, kemudian perlakuan P1L1 sebesar 25\% dan yang paling rendah perlakuan P2L1 sebesar 13\%.

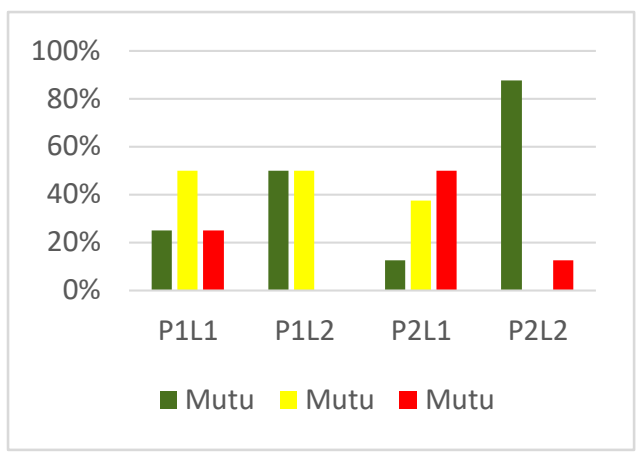

Gambar 2. Diagram penilaian mutu kebersihan karkas

Faktor mutu kebersihan menunjukkan efektifitas cara pembersihan bulu halus yang digunakan yaitu dengan lilin siongka dan pemanggangan. Perlakuan P2L1 memiliki persentase mutu I paling rendah karena sebagian besar karkas masih terdapat bulu tunas yang menyebar pada bagian dada dan bagian karkas lainnya. Bulu tunas tersebut tidak hilang sepenuhnya dengan proses pemanggangan, yang terbakar hanya bagian ujung bulu hingga pangkal bulu saja. Dari hasil tersebut menunjukkan cara pembersihan bulu halus 
dengan pemanggangan lebih efektif dibandingkan dengan lilin siongka pada jenis itik hibrida, sedangkan pada jenis lokal pembersihan bulu halus dengan lilin siongka masih lebih baik dibandingkan dengan pemanggangan.

\section{Tingkat Kesukaan Karkas Itik}

Tingkat kesukaan karkas itik dinilai menggunakan panelis tidak terlatih sebanyak 25 orang. Panelis diberikan form penilaian tingkat kesukaan (uji hedonik) kemudian menilai secara langsung tingkat kesukaan berdasarkan warna, aroma dan kebersihan terhadap karkas yang disajikan. Hasil analisis ragam skor respon panelis terhadap karkas itik yang mendapatkan perlakukan percobaan sebagaimana tabel 4 .

Skor warna karkas yang diperoleh pada penelitian ini berkisar antara 3,00 3,88 dengan kategori netral dan secara statistik tingat kesukaan terhadap warna tidak berbeda nyata $(P>0,05)$. Hasil penelitian terhadap aroma karkas itik yang mendapatkan perlakuan pembersihan bulu halus berbeda menunjukkan skor berkisar antara $2,72-3,88$ dengan kategori tidak suka - netral. Hasil analisis statistik bahwa tingkat kesukaan karkas itik yang mendapatkan pembersihan dengan pemanggangan (P2L1 dan P2L2) lebih tinggi $(P<0,05)$ dibandingkan dengan karkas itik yang mendapatkan pembersihan dengan lilin siongka. Hasil penelitian terhadap tingkat kesukaan panelis terhadap kebersihan karkas itik menunjukkan skor 3,12 - 4,08 dengan kategori netral - suka. Hasil analisis statistik tingkat kesukaan kebersihan karkas itik hibrida dengan pembersihan lilin siongka mempunyai nilai lebih paling tinggi $(P<0,05)$, sedangkan tiga perlakukan lainnya tidak berbeda nyata.

Tabel 4. Hasil pengujian tingkat kesukaan karkas itik

\begin{tabular}{lllll}
\hline \multicolumn{1}{c}{ Parameter } & P1L1 & P1L2 & P2L1 & P2L2 \\
\hline Warna & $3,00^{\mathrm{a}}$ & $3,28^{\mathrm{a}}$ & $3,36^{\mathrm{a}}$ & $3,88^{\mathrm{a}}$ \\
Aroma & $2,92^{\mathrm{a}}$ & $2,72^{\mathrm{a}}$ & $3,76^{\mathrm{b}}$ & $3,88^{\mathrm{b}}$ \\
Kebersihan & $3,32^{\mathrm{a}}$ & $4,08^{\mathrm{b}}$ & $3,12^{\mathrm{a}}$ & $3,56^{\mathrm{a}}$ \\
\hline
\end{tabular}

\section{Mikrobiologi Karkas Itik}

Hasil pengujian laboratorium cemaran mikrobiologi Eschericia coli dan Salmonella sp pada karkas itik yang mendapatkan perlakukan pembersihan bulu halus dengan lilin siongka dan pemanggangan sebagaimana tabel 5. Dari hasil uji laboratorium cemaran mikrobiologi masih diidentifikasi adanya bakteri Eschericia coli dengan jumlah yang beragam. Namun yang konsisten menunjukkan angka cemaran mikroba tertinggi adalah 
perlakukan P2L1 dimana pada penilaian mutu kebersihan karkas juga mendapatkan nilai terendah. Hal tersebut menunjukkan bahwa adanya korelasi kebersihan karkas dengan kandungan Eschericia coli. Eschericia coli sering juga didapatkan pada karkas yang masih terdapat bulu [12]. Begitu juga dengan perlakukan P2L2 masih terdapat bakteri Eschericia coli meskipun jauh lebih baik dari perlakukan P2L1. Hal tersebut dimungkinkan masih terdapat sedikit bulu dan bakteri e coli tahan terhadap pemanasan.

Sebagaimana dilaporkan oleh untuk menginaktifkan Escherichia coli GMP pada proses penggumpalan tahu membutuhkan waktu 2,72 menit pada suhu $60^{\circ} \mathrm{C}$, total ratarata populasi 1,9x101 CFU/g [14]. Adapun pada perlakukan P1L1 dan P1L2 masih ditemukan adanya bakteri Eschericia coli dimungkinkan karena perpaduan antara tingkat kebersihan dimana paling tinggi hanya 50\% karkas dengan mutu I dan kontaminasi air. Kontaminasi Eschericia coli pada daging dan olahannya biasanya berasal dari air yang digunakan pada saat pencucian karkas [5].

Dari hasil uji laboratorium cemaran mikrobiologi pada semua perlakukan menunjukkan hasil negative salmonella. Bakteri salmonella maupun sporanya mudah mati pada pemanasan [19]. Hal tersebut merupakan keuntungan tersendiri dari pembersihan bulu itik yang menggunakan lilin siongka maupun pemanggangan.

Tabel 5. Hasil pengujian Eschericia coli dan Salmonella sp

\begin{tabular}{lrrrrr}
\hline \multirow{2}{*}{ Parameter } & Bagian & \multicolumn{4}{c}{ Perlakuan } \\
\cline { 3 - 6 } Eschericia coli & Karkas & \multicolumn{1}{c}{ P1L1 } & \multicolumn{1}{c}{ P1L2 } & \multicolumn{1}{c}{ P2L1 } & \multicolumn{1}{c}{ P2L2 } \\
\cline { 3 - 6 }$($ MPN/g) & Dada & $24 \times 10^{1}$ & $2,3 \times 10^{1}$ & $110 \times 10^{1}$ & $24 \times 10^{1}$ \\
& Paha & $7,5 \times 10^{1}$ & $0,36 \times 10^{1}$ & $110 \times 10^{1}$ & $0,92 \times 10^{1}$ \\
& Dada & $4,3 \times 10^{1}$ & $46 \times 10^{1}$ & $110 \times 10^{1}$ & $15 \times 10^{1}$ \\
& Paha & $24 \times 10^{1}$ & $46 \times 10^{1}$ & $110 \times 10^{1}$ & $0,36 \times 10^{1}$ \\
Salmonella & Dada & Negatif & Negatif & Negatif & Negatif \\
(per 25 g) & Paha & Negatif & Negatif & Negatif & Negatif \\
& Dada & Negatif & Negatif & Negatif & Negatif \\
& Paha & Negatif & Negatif & Negatif & Negatif \\
\hline
\end{tabular}




\section{KESIMPULAN}

Berdasarkan hasil penelitian dapat disimpulkan beberapa hal sebagai berikut :

1. Perbandingan kualitas fisik karkas itik ditinjau dari aspek persentase karkas, persentase mutu karkas faktor mutu keutuhan dan kebersihan yaitu pembersihan bulu halus menggunakan lilin siongka menghasilkan persentase karkas dan mutu karkas faktor keutuhan yang lebih baik dibandingkan dengan pemanggangan sedangkan pada mutu karkas faktor kebersihan pemanggangan lebih baik daripada lilin siongka;

2. Tingkat kesukaan karkas itik ditinjau dari aspek warna, aroma dan kebersihan yaitu warna karkas menunjukkan hasil tidak berbeda nyata, namun terhadap aroma karkas menunjukkan pembersihan menggunakan pemanggangan lebih disukai dibandingkan karkas itik hasil pembersihan dengan lilin siongka sedangkan tingkat kesukaan terhadap kebersihan karkas itik menunjukkan karkas itik hibrida dengan pembersihan lilin siongka (P1L2) mempunyai skor paling tinggi

3. Kandungan bakteri Eschericia coli tertinggi adalah perlakukan P2L1 dimana pada penilaian mutu karkas faktor mutu kebersihan juga mendapatkan nilai terendah sedangkan untuk bakteri salmonella semua perlakukan menunjukkan hasil negatif;

\section{DAFTAR PUSTAKA}

Aberle ED, Forrest JC. Gerrand DE, Mills EW. 2001. Principles of Meat Science. Fourth Ed. Amerika. Kendal/Hunt Publishing Company.

Badan Standarisasi Nasional. 2008. Metode pengujian cemaran mikroba dalam daging, telur dan susu serta hasil olahannya. SNI 2897:2008

Badan Standarisasi Nasional. 2009. Mutu Karkas dan Daging Ayam. SNI 3924:2009

Brooks GF, Butel JS, Morse SA. 2005. Medical Microbiology. McGrawHills Companies Inc

Buckle KA, Edwads RA, Fleet GH, Wooton M. 2009. Ilmu pangan. Purnomo $\mathrm{H}$, Adiono, penerjemah. Jakarta (Indonesia): UI Press.

Dewanti, S. and M.T. Wahyudi. 2011. Antibacteri activity of bay leaf infuse (Folia Syzygium polyanthum Wight) to Escherichia coli in-vitro. J. Med. Planta. 1(4):78-81.

Dewi ES, El Latifa S, Fawwarahly, dan R Kautsar. $2016 . \quad$ Kualitas 
Mikrobiologis Daging Unggas di RPA dan yang Beredar di Pasaran. Jurnal IImu Produksi dan Teknologi Hasil Peternakan ISSN 2303-2227. Vol. 04 No. 3 Oktober 2016. Hal:379-385

Direktorat Jenderal Peternakan dan Kesehatan Hewan. 2010. Pedoman Produksi dan Penanganan Daging Ayam Yang Higienis

Dinas Ketahanan Pangan Kelautan dan Pertanian. 2020. Data Produksi Daging di DKI Jakarta Tahun 2019. http://data.jakarta.go.id

Hariyadi RD. 2005. Bakteri Indikator Sanitasi dan Keamanan Air Minum. http://web.ipb.ac.id/ tpg/de/ pubde_fdsf_bctrindktr.php

Jawetz, E., J.L. Melnick, E.A. Adelberg, G.F. Brooks, J.S. Butel, dan L.N. Ornston. 2007. Mikrobiologi Kedokteran. (Diterjemahkan Hartanto, H., C. Rachman, A. Dimanti, dan A. Diani). Edisi ke- 20. ECG. Penerbit Buku Kedokteran, Jakarta

Kabir, K.A. 2010. Dietary bioflavonoids inhibit Escherichia coli ATP synthase in a differential manner. Int. J. Biol. Macromolecules. $46: 478-486$.
Kirk, R. E dan Othmer, D. F. 2007. Encyclopedia of Chemical Technology 4th. Volume Ke-21. The Interscience Encyclopedia, Inc. New York.

Mailia, R., Bara Yudhistira, Yudi Pranoto, Saiful Rochdyanto, Endang Sutriswati Rahayu. 2015. Ketahanan Panas Escherichia coli, Staphylococcus aureus, Bacillus cereus dan Bakteri Pembentuk Spora yang Diisolasi dari Proses Pembuatan Tahu di Saudagaran Yogyakarta. Agritech Vol. 35, No. 3

Montney, G. J. 1983. Poultry Products Technology, Second edition. The avi publishing company INC, USA.

Nugroho, A., S. B. M. Abduh dan L. D. Mahfudz. 2013. Pengaruh Lama Scalding Dalam Lilin Panas Terhadap Kualitas Karkas, Kadar Lemak dan Susut Masak Daging Itik. Animal Agriculture Journal 2(4): $45-55$

Nuraini, H., Rudy Priyanto, Edit Lesa Aditya, Niken Ulupi, Bramada Winiar Putra. 2020. Manajemen Rumah Pemotongan Hewan. IPB Press. Bogor

Purba, Maijon. 2014. Pembentukan Flavor Daging Unggas oleh Proses 
Pemanasan dan Oksidasi Lipida.

Wartazoa Vol. 24 No. 3. Hal:109118

Rihastuti, RA dan Soeparno. 2014. Kontrol

Kualitas Pangan Hasil Ternak.

Gadjah Mada University Press: Yogyakarta

Rukmana, H. Rahmat. 2014. Panduan Lengakp Ternak Itik Petelur dan Pedaging Secara Intensif. Lily Publisher Jakarta

Saputra, G. A., W. Sarengat dan S. B. M. Abduh. 2014. Aktivitas Air, Total Bakteri dan Drip Loss Daging Itik Setelah Mengalami Scalding Dengan Malam Batik. Animal Agriculture Journal 3(1): 34-40

Sastrosupadi, Adji. 2000. Rancangan Percobaan Praktis Bidang Pertanian. Penerbit Kanisius: Yogyakarta

Setyaningsih, Dwi., A, Apriyantono, Sari, M.P. 2010. Analisis Sensori untuk Industri Pangan dan Agro. IPB Press. Bogor.

Soekarto, S.T. 1985. Penilaian Organoleptik Pusat Pengembangan Teknologi Pangan. IPB Press. Bogor
Soekarto, S.T, Prof. Em. 2020. Teknologi Hasil Ternak. IPB Press. Bogor

Soeparno. 2009. Ilmu dan Teknologi Daging. Universitas Gadjah Mada. Yogyakarta.

Soeparno. 2011. Ilmu Nutrisi dan Gizi Daging. Universitas Gadjah Mada. Yogyakarta.

Stephen, Usam. 2014. How to prepare duks for the market. TT: Ag Ext 00:12. First Published June 2001, revised April 2014

Sumual, M. A., R. Hadju., M.D. Rontinsulu, dan S. E. Sakul. 2014. Sifat organoleptik daging broiler dengan lama perendaman berbeda dalam perasan lemon cui (Citrus microcarpa). Jurnal Zootek. 34 (2):139-147.

Supriyadi. 2019. Super Lengkap Itik Panduan Beternak dan Berbisnis Itik dari Hulu Hingga Hilir. Penebar Swadaya Jakarta

Winarno, F.G. 2002. Kimia Pangan dan Gizi. Jakarta: PT Gramedia Pustaka Utama 
Jurnal IImiah Respati 